\title{
Issues in Implementation of Coeducation in Turkish Education System: A Historical Research on 1869 Statute on General Education
}

\author{
Selman Tunay Kamer ${ }^{1}$ \\ ${ }^{1}$ Faculty of Education, Kastamonu University, Kastamonu, Turkey \\ Correspondence: Selman Tunay Kamer, Faculty of Education, Kastamonu University, Kastamonu, Turkey. \\ E-mail: tkamer@kastamonu.edu.tr
}

Received: September 28, 2016

Accepted: October 30, 2016

Online Published: March 29, 2017

doi:10.5539/ies.v10n4p1

URL: https://doi.org/10.5539/ies.v10n4p1

\begin{abstract}
Though the Imperial Edict of Gülhane, which is regarded as the real beginning of modernization in the Ottoman Empire, does not contain any direct article on education, Tanzimat (Reorganization of the Ottoman Empire) and the process following it directly affected the education system in the country. The boards formed and the regulations issued in that period were of great importance. Maarif-i Umumiye Nizamnamesi (Statute on General Education) prepared by 7-person committee led by the Minister of Education Saffet Pasha under the influence of the French education system and published on the $1^{\text {st }}$ of September 1869 is a comprehensive text regulating education. This statute, which consists of 198 articles, involves teacher training and placement, determination of school stages, principles about inspection and assessment, educational administration, right to education, training allowances, provincial organization, testing system, and so on. Coeducation was not a problem in the Ottoman Empire because girls were allowed to receive only primary education. With the 15th article of the Statute on General Education, coeducation was prohibited. However, some documents in the state archives prove that some schools and practices disobeyed this ban. That indicates that not every law introduced was enforced across the country. This may have been because decisions were implemented differently in different cities or regions due to the non-equality of conditions.
\end{abstract}

Keywords: Maarif-i Umumiye Nizamnamesi, coeducation, Turkish education system, sıbyân schools, rüşdiyye schools

\section{Introduction}

The Imperial Edict of Gülhane, which is regarded as the real beginning of modernization in the Ottoman Empire, does not contain any direct article on education. However, during the Tanzimat (Reorganization of the Ottoman Empire) period, educational boards were formed; boarding university was opened; sultanî schools (high schools) started to take part in education; and attempts were made to multiply rüsstiye schools (secondary schools), the first stage of primary education (Altın, 2008).

After Tanzimat was proclaimed, educational issues were addressed independently. In addition, attention was focused on schools preparing students for secondary education institutions. Abdülmecid I, who wanted the reforms set forth in Tanzimat Fermanı to be implemented in fields other than military, issued an edict in 1845 and stated that progress on the way to reform would be possible only if importance was attached to education. After this edict was issued, it was decided to form some boards under the names of Meclis-i Maarif-i Muvakkat (Temporary Board of Education) and Meclis-i Imariye (Board of Reconstruction) in Istanbul and some provincial areas so that reconstruction and improvement works would be performed (Kodaman, 1999).

In 1845, Meclis-i Maarif-i Muvakkat (Temporary Board of Education) was formed for the discussion of educational affairs. This board divided the education system into stages: primary education; secondary education; and university education. The board also made a decision for the establishment of Meclis-i Maarif-i Daimi (Permanent Board of Education). Pursuant to this decision, Meclis-i Maarif-i Umumiye (General Education Board) was set up in 1846. It was the first board that made important decisions such as making primary education compulsory, abolishing beating in educational institutions, introducing primary education exit tests, and accepting only those students succeeding in the said tests to rüşdiye (secondary) schools and regulated educational affairs directly and continuously. Mekatib-i Umumiye Nezareti (General Directorate of Schools) that would serve based on the foregoing was set up on the $8^{\text {th }}$ of November 1846 (Koçer, 1991; Türk, 2003). 
It is clear that a new era started in the Ottoman Empire in 1854. The Crimean War against Russia manifested the weakness of the Ottoman Empire and the inadequacy of reforms. As a result, an extensive reform project was prepared. This reform project was announced in 1856 under the name of Islahat Fermanı (Imperial Reform Edict), and with an article inserted in the Treaty of Paris of 1856, the supervision of European countries in the implementation of reforms was accepted (Kodaman, 1999:14-15).

The opening of new schools as a result of the above-mentioned developments brought along a need for a more comprehensive organization in the field of education. Maarif-i Umûmiye Nezareti (The Ministry of Public Education) was formed on the $17^{\text {th }}$ of March 1857 under the presidency of a minister from the council of ministers. In this way, schools were put under the management of a board and a minister (Kodaman, 1999:16; Türk, 2003).

In the Tanzimat period, non-madrasah formal education was divided into stages: primary education; secondary education; and higher education. Though they partly remained on paper, certain fundamental changes were intended, and the foundations of vocational and technical training were laid. First teacher training vocational schools and first secondary schools for girls were opened; the dressing of students and teachers was determined; foot whipping as a disciplinary instrument was abolished; and the importance of public education was realized (Akyüz, 2015).

The aim of this study is to show that articles related to education in 1869 Statute on General Education could not be enforced completely. To this end, an attempt was made to answer the below-mentioned questions:

1) Were the articles on the implementation of education in the Statute obeyed?

2) Was there any article on coeducation in the Statute on General Education?

\section{Method}

Being qualitative in nature, the current study has been conducted as a historical research about 1869 Statute on General Education and coeducation practices. As is known, qualitative research is a research type that is based on induction and tries to describe phenomena and events in their own natural environments and reflect the points of view of participants through data collection tools such as observation, interview, and document analysis (Merriam, 2001). Historical research in education is important because of several reasons. The findings of such research allow educators to learn from past findings and mistakes, realize educational reform needs, and predict future tendencies to a certain degree. Moreover, historical research requires a systematic search of sources and documents covering facts about the questions of the historian about the past.

To answer the research questions, the current study collected data from the articles and official documents (letters, complaints etc.) from the State Archives of the Prime Ministry of the Republic of Turkey. The current study has been aimed to present educational practices in the past. Hence 1869 Statute on General Education, the first general education regulation in the country, was targeted in this study.

\section{Findings and Interpretation}

\subsection{Statute on General Education}

The Statute on General Education dated the $1^{\text {st }}$ of September 1869 prepared under the leadership of Saffet Pasha who worked as the minister of education between 1867 and 1871 was a comprehensive text regulating education (Akyüz, 2015).

A 7-person committee made up of the prominent intellectuals of the time such as Kemal Pasha (Head of the Council of State Department of Education), Sadullah Pasha, Recaizade Mahmut Ekrem, Ebuziya Tevfik, Mehmet Mansur, Dadyan Artin, and Dragon Tzankoff examined what France did and wanted to do in the field of education from the French Revolution until then separately and prepared the Statute by taking into consideration the conditions of the country (Koçer, 1991, p. 83). Çadırcı (1991) reports that France sent a diplomatic note to the Ottoman Government on the $22^{\text {nd }}$ of February 1867, two years before the issue of the Statute, and that such note involved requests about education, too. The note involved such educational issues as teacher training, the preservation of Christian schools, opening new Christian schools, making all schools in the country (Ottoman, minority, foreign) mixed, and opening libraries that would be used by all. Thus, French influence is visible in the Statute.

The Statute on General Education consists of five chapters and 198 articles. The first chapter (1-130) is about school types; the second chapter (131-152) is about the central organization of the ministry; the third chapter (153-177) is about testing and graduation procedures; the fourth chapter (178-191) is about teaching features; and the last chapter (192-198) is about the funding of education. The Statute also involves teacher training and 
placement, right to education, principles of inspection and assessment, educational administration, determination of school stages, training allowances, testing systems, and provincial organization (Note 1).

The Statute was important in that it made a distinction between public schools and private schools, ordered the opening of a school in every neighborhood and every village, regulated teacher appointment, determined the durations of sibyan schools, made school attendance compulsory and ensured that it would be followed, regulated teaching methods, introduced measures concerning teacher training, and set up the educational organization (Demirtaş, 2007). According to Güven (2014), the Statute aimed to appoint at least one teacher to every school as in the Western educational institutions and contained an article stating that teachers would be provided with a salary and their financial situation would be improved. Doğan (2010) says that the Statute mentions all educational issues other than art schools.

Though the Statute on General Education attempted to give a new shape to primary schools, the sibyan schools which provided education through traditional ways were not intervened in. Iptidai schools (modern primary schools) were opened in accordance with the usul-i cedid (new education system) for the implementation of the Statute. In this way, primary schools were divided into two: sibyan schools (classical primary schools) affiliated to the Ministry of Foundations and iptidai schools (modern primary schools) affiliated to the Ministry of Education (Akyüz, 2015).

\subsection{The Statute on General Education and the Implementation of Coeducation}

Coeducation of boys and girls in iptidai and sibyan schools was forbidden pursuant to the Statute on General Education. The $15^{\text {th }}$ article of the Statute on this subject is as follows: "When there are two sibyan schools for a community in a neighborhood or village and there is no problem in regard to the location of the buildings, one of these schools shall be allocated for the male children of this community while the other one shall be allocated for the female children. In the event that it is not possible to make such discrimination, the female children of the community may be accepted to the males' sibyan school until an independent girls' sibyan school is opened. However, if such a necessity comes up, girls and boys shall not be taught together in the same classroom."

The Statute on General Education states that separate schools have to be opened for girls. If there are two sibyan schools in a neighborhood or village, one of them has to be allocated for girls. Otherwise, girls will attend the sibyan school attended by boys until a new school is opened, but they will be separate from boys in seating order As cited by Somel (2000), girls and boys studied in different periods of the day and in different parts of the schools in coeducational iptidai schools in Thessaloniki. However, there were also schools violating the coeducation ban introduced by the Statute. The inspection in schools in 1873 showed that coeducation was implemented in some schools. Therefore, the directive prepared by the Board of Education was sent to neighborhood imams who were requested to read it in mosques and announce it to teachers and the public (Kamer, 2013).

It was determined that boys were accepted to a girls' school located in Beykoz. As a result, the teacher of the school was warned. Beykoz Board of Alderman wrote and sent a report to the Ministry of Education. It was stated in the report that the teacher accepted boys over the age of 14 to the school despite the warning, and a solution was requested in that matter (BOA, MF. VRK., 3/139. 14 Za 1302 (Hijri)).

In 1874, it was requested to separate girls and boys who received coeducation in Siğırcılar School and Haracılar School in Unkapanı (BOA, MF.MKT. 17/66 11/M /1291 (Hijri)). In the same year, a decision was made to separate girls and boys and allocate separate schools for them in the first meeting of the Commission of Education held in Çorlu district (BOA, MF.MKT. 34/164. 15/Ra/1293 (Hijri)).

Upon some unconfirmed information about the acceptance of girls to some sons' schools and the acceptance of boys to some girls' schools, a warning was given to central teachers in Istanbul in 1885. This warning focused on certain problems resulting from the above-mentioned situation. As a result, some "rows" took place in Anadoluhisarı. They were quelled with difficulty. The director of education of Istanbul Province requested that such "inappropriate" situations would not be allowed from then on and said that principals and teachers would be held responsible if such situations continued (Erdem, 2007).

In 1890, it was reported to Erzurum Province that coeducation of female and male primary school students in Kuzican Middle School was not appropriate (Kamer, 2013).

With the directive issued for primary schools in 1892, it was forbidden for boys and girls to go to the same school when there were separate schools for girls and boys in a neighborhood (Erdem, 2007).

In 1902, Hüdavendigar Province gave a notice for the separation of girls and boys receiving coeducation in schools in Kütahya (BOA, MF.MKT., 664/35. 26/C/1320 (Hijri)). In 1902, it was determined that the teachers of 
Çanakkale İnas School accepted male students to the school, and Governorship of Biga conducted an investigation in this matter (BOA, MF.MKT., 640/40. 25/Ra/1320 (Hijri)).

On the other hand, it is stated in the Statute on General Education that coeducation can be implemented in sibyan schools when there is no other option. Girls and boys had to be placed in the same classrooms because of immigrant settlement in 1880 (Kamer, 2013). Likewise, since the girls' school in the vicinity of Topkapı was distant to the settlement, girls were allowed to attend the boys' school until a new building was constructed nearby. Girls attending the girls' iptidai school located in Düğmeciler neighborhood of Eyüp were allowed to go to the boys' school in winter months because of the brooks and desolate streets on the school road (Erdem, 2007) On the other hand, sending girls to the schools on the tramline in Aksaray and Koska was dangerous in 1874, and they were not allowed to receive education in boys' Yolgeçen School divided into two flats in Laleli (BOA, MF.MKT., 16/162. 26/Za/1290 (Hijri)). It is clear that there were differences from city to city in practice.

Nurdoğan (2005) reports that separate girls' iptidai schools were opened in villages or neighborhoods when the number of girls reaching the age of education was over 50 , but girls and boys mostly received coeducation in iptidai schools because of the inadequacy of the number of teachers. Nurdoğan (2005) gives a report sent from the residents of Samatya and its vicinity in 1885 as an example. It is stated in the report that because the girls' iptidai school could not be opened, girls and boys received coeducation in the iptidai schools there. The largest number of formal coeducational iptidai schools was in Samatya in Istanbul in 1911 (Kamer, 2013).

In Istanbul, there were 16 boys', 16 girls', and 211 coeducational iptidai schools in the 1894-1895 academic year; 19 boys', 22 girls', and 203 coeducational iptidai schools in the 1895-1896 academic year; and 13 girls', 7 boys', and 254 coeducational iptidai schools in the 1907-1908 academic year (Erdem, 2007). It is clear that most of the iptidai schools provided coeducation. However, according to the Statute on General Education, separate schools had to be opened for girls. The Statute allowed girls to attend the boys' schools only when there was no separate school for girls and only until a separate school was opened for them. Data provided above in regard to 1894-1895, 1895-1896, and 1907-1908 academic years indicate that the number of schools providing coeducation increased gradually.

\section{Conclusion and Discussion}

Tanzimat Fermanı (the Imperial Edict of Gülhane), which is regarded as the real beginning of modernization in the Ottoman Empire, does not contain any direct article on education. However, the architects of the Tanzimat (Reorganization) period knew the importance of education. As a matter of fact, during the Tanzimat Period, the Board of Public Education was formed; boarding university was opened; sultanî schools (secondary schools) started to take part in education; and attempts were made to multiply rüşdiye schools (middle schools), the first stage of secondary education.

Although the $15^{\text {th }}$ article of the 198-article Statute on General Education contains explicit statements prescribing the avoidance of coeducation, coeducation was implemented in some cities, which is seen in the examples provided above. There were differences from city to city also in implementing coeducation temporarily when there was no other option. Erdem (2007) discusses in detail the violation of the $16^{\text {th }}$ and the $28^{\text {th }}$ articles of the Statute on General Education which state that female teachers have to be appointed to girls' sibyan schools and rüşdiye schools and that only old and well-behaved men have to be appointed to these schools until sufficiently competent female teachers are made ready for teaching through training. That also indicates that not every law introduced was implemented across the country. This may have been because decisions were implemented differently in different cities or regions due to the non-equality of conditions.

Centralization, favor in appointment and promotion, imbalance between authority and responsibility, lack of resources, hastiness in innovative practices, and implementation of novelties without enough examination and research are problematic practices of the Turkish education system that started in the Tanzimat period and have survived until today (Cemaloğlu, 2005). Such issues have continued during the Constitutional period (Kamer, 2014). One of the biggest indicators of this situation is that the articles of the Statute on General Education concerning coeducation were not obeyed, which is clearly seen in the examples provided above.

\section{References}

Akyüz, Y. (2015). Türk Ĕ̈itim Tarihi M. Ö. 1000-M.S. 2015 (History of Turkish Education 1000 B.C.-2015 A.D.). Ankara: Pegem Akademi Yayınları.

Altın, H. (2008). 1869 Maarif-i Umumiye Nizamnamesi ve Öğretmen Yetiştirme Tarihimizdeki Yeri (1869 Statute on General Education and Its Place in Our History of Teacher Training). Review of the Faculty of Divinity of Firat University, 13(1), 271-283. 
BOA, MF.VRK., 3/139. 14 Za 1302 (Hijri) (State Archives of the Prime Ministry of the Republic of Turkey).

BOA, MF.MKT. 17/66 11/M/1291 (Hijri).

BOA, MF.MKT. 34/164. 15/Ra/1293 (Hijri).

BOA, MF.MKT., 640/40. 25/Ra/1320 (Hijri).

BOA, MF.MKT., 664/35. 26/C/1320 (Hijri).

BOA, MF.MKT.. 16/162. 26/Za/1290 (Hijri).

Çadırc1, M. (1991). Tanzimat Döneminde Anadolu Kentlerinin Sosyal ve Ekonomik Yapıları (The Social and Economic Structures of Anatolian Cities in the Tanzimat Period). Ankara: TTK

Cemaloğlu, N. (2005). Osmanlı Devleti'nde Yapılan Tanzimat Reformlarının Eğitim Sistemine Etkileri, Uygulamaları ve Sonuçları (1839-1876) (The Effects of Tanzimat Reforms in the Ottoman Empire on the Education System, Their Implementation, and Their Results [1839-18769]). Manas Journal of Social Studies, 7(14), 153-165.

Demirtaş, Z. (2007). Osmanlı'da Sıbyan Mektepleri ve İlköğretimin Örgütlenmesi (Sibyan Schools and the Organization of Primary Education during the Ottoman Period). Firat University Journal of Social Science, 17(1), 173-183.

Doğan, İ. (2010). Türk Eğitim Tarihinin Ana Evreleri: Kurumlar, Kişiler, Söylemler (The Main Stages of the Turkish Education History: Institutions, People, Discourses). Ankara: Nobel Yayın Dağıtım.

Erdem, Y. T. (2007). II. Meşrutiyet'ten Cumhuriyet'e Kızların Eğitimi (The Education of Girls from the Second Constitutionalist Era to the Republic). Marmara University Institute of Turkic Studies Department of Turkish History Major of History of Modern Age Doctoral Dissertation, Istanbul.

Güven, İ. (2014). Türk Eğitim Tarihi (History of Turkish Education). Ankara: Pegem Akademi Yayınları

Kamer, S. T. (2013). Türk Eğitim Sisteminde Karma Eğitime Illişkin Fikirler, Tartışmalar ve Uygulamalar (1908-1950) (Ideas, Discussions, and Practices Concerning Coeducation in the Turkish Education System [1908-1950]). Ankara University Institute of Educational Sciences Department of Social and Historical Foundations of Education Doctoral Dissertation, Ankara.

Kamer, S. T. (2014). II. Meşrutiyet Dönemi İlköğretimde Karma Eğitim Uygulamaları ve Yasal Düzenlemeler (Coeducation Applications and Legal Regulations in Primary Education during the Second Constitutional Period). e-International Journal of Educational Research, 5(3).

Koçer, H. A. (1991). Türkiye'de Modern Eğitimin Doğuşu ve Gelişimi (The Birth and Development of Modern Education in Turkey). Istanbul: Milli Eğitim Bakanlığı Yayınları.

Kodaman, B. (1999). Abdülhamit Devri Eğitim Sistemi (Education System in the Abdul Hamid Period). Ankara: TTK Basımevi.

Mahmud Cevad İbnü'ş-Şeyh Nâfi. (2002). Maarif-i Umumiye Nezareti Tarihçe-i Teşkilat ve İcratı (The History of Organization and Activities of the Ministry of Public Education). (Edited M. Ergün, T. Duman, S. Arıbaş, H. H. Dilaver). Ankara: Milli Eğitim Bakanlığı Yayınları

Merriam, S. B. (2001). Qualitative research and case study applications in education. San Francisco: Jossey-Bass.

Nurdoğan, A. M. (2005). Osmanlı Modernleşme Sürecinde İlköğretim (1869-1922) (Primary Education in the Ottoman Modernization Process [1869-1922]). Marmara University Institute of Turkish Studies Unpublished Doctoral Dissertation. Istanbul

Somel, S. A. (2000). Osmanlı Modernleşme Döneminde Klz Eğitimi (Girls' Education in the Ottoman Modernization Period). Kebikeç, 10, Ankara.

Türk, E. (2003). Dünden Bugüne Milli Eğitim Bakanlı̆ğ Kuruluş ve Tarihsel Süreç (The Ministry of National Education from Past to Present: Its Foundation and Historical Process). Bilim ve Aklın Aydınlı̆̆ında Eğitim, 4(44). MEB Basımevi,

\section{Notes}

Note 1. For the Statute, see the book titled "Maarif-i Umumiye Nezareti Tarihçe-i Teşkilat ve İcraatı (The History of Organization and Activities of the Ministry of Public Education" written by Mahmud Cevad 
İbnü'ş-Şeyh Nâfi and edited by Mustafa Ergün, Tayyip Duman, Sebahattin Arıbaş, and H. Hüseyin Dilaver.

Note 2. A brief version of this study has been presented at International Journal of Arts \& Sciences' (IJAS) International Conference for Education 23-27 May 2016. Boston, Massachusetts.

\section{Appendix}

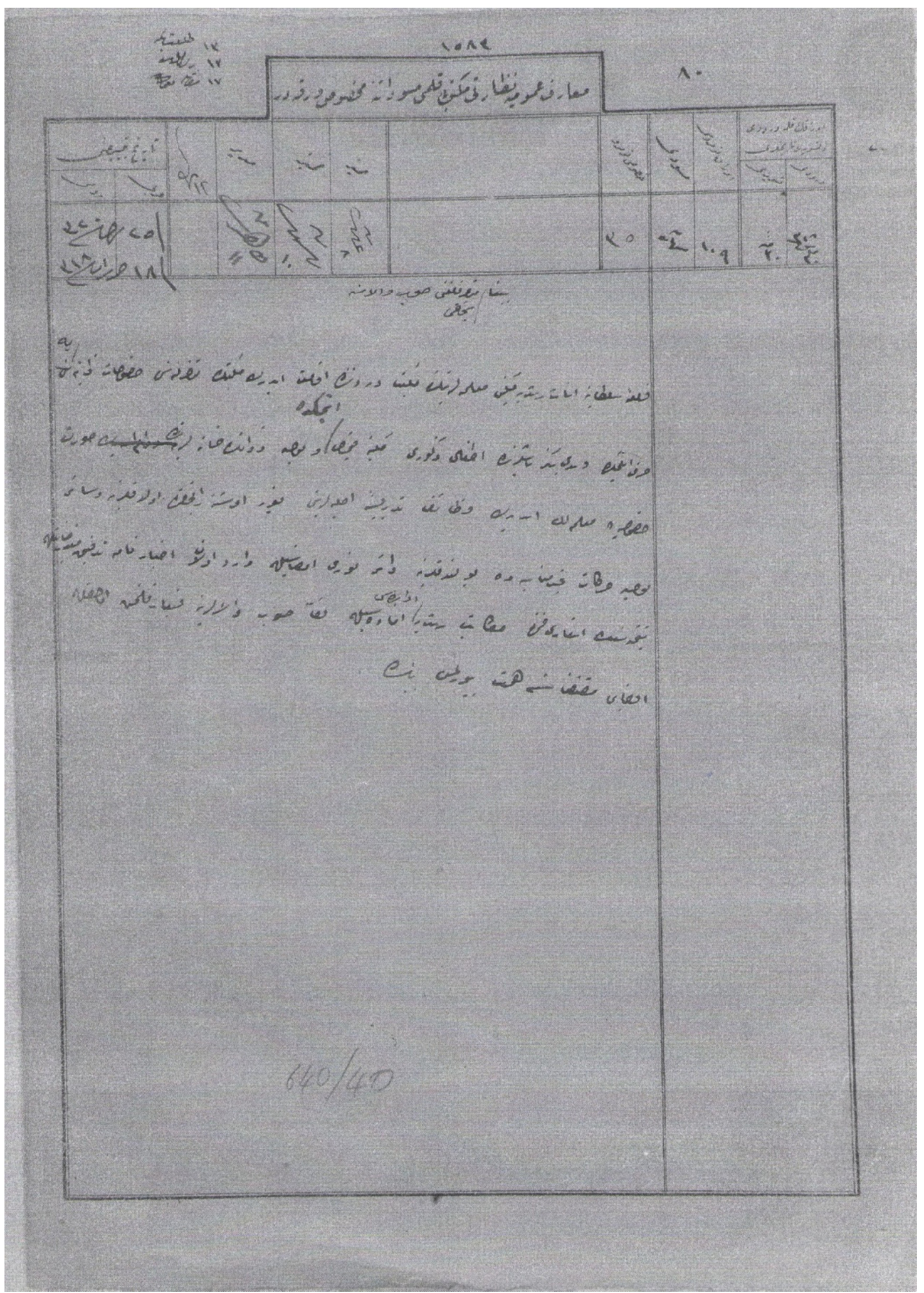


The document proving male students' acceptance to the girl school in 1902

Document translation to English: As of the date of July $2^{\text {nd }}, 1902$, it was determined that the teachers of male students were being accepted to Çanakkale İnas School, and that Governorship of Biga conducted an investigation in this matter.

\section{Copyrights}

Copyright for this article is retained by the author(s), with first publication rights granted to the journal.

This is an open-access article distributed under the terms and conditions of the Creative Commons Attribution license (http://creativecommons.org/licenses/by/4.0/). 